\title{
Contemporary Political Communication
}

\author{
Interview with Prof. Gianpietro Mazzoleni \\ UNIVERSITY OF MILAN, ITALY
}

You have been working on the next edition (4th edition) of your successful handbook of political communication (La comunicazione politica) that was published first in 1998. It is been more than 20 year since then. In the meantime, there were two other editions of that book: in 2004 and 2012. Do you feel like you need to write the new edition from scratch or are there parts that do not require to be changed? What has changed the most and what seems to be quite constant in political communication over these two decades?

The handbook saw the light in the late 1990s just a few years from the appearance on the domestic political scene of a media tycoon, Silvio Berlusconi, who for better or for worse, marked a revolution in politics and in political communication. After decades of neglect by political science and other social sciences for the communication dimensions in politics, the interest in political communication issues grew fast, especially among university students and young researchers. The aim was to provide a comprehensive overview of what comparative scholarship had produced in more than half century of research and theoretical reflection. The editions that followed in subsequent years were updates along some developing lines of research, linked with dramatic political events like terrorism and with the diffusion of the internet.

In the past two decades, since the first publication, the worlds of politics and communications have known an unprecedented acceleration of processes and dynamics at all levels. It is a widely shared acknowledgement that research in all subfields of political communication has since grown enormously and has taken a strong inter-disciplinary character. It is then the right time to work around a completely new account of the state of the discipline. I am summarizing in two chapters the theories and evidences that were the substance of our scholarship for half a century, that are still largely usable, and write new chapters on topics and issues that are at the center of the attention of international research, like disinformation, populist discourse, big data and computational analysis, effects of social 
media, etc. It is a challenging task to make a synthesis of a real 'deluge' of published works, many of which, alas, provide only 'piecemeal' accounts of findings.

Which classic (traditional) concepts and theories you still find the most useful for studying the modern political communication? And which of the more recent concepts do you find the most relevant and important?

The easy answer to this question is to suggest checking the multiple entries of renowned authors in the International Encyclopedia of Political Communication (Wiley 2016), that I had the honor to edit on behalf of the ICA. One can find an in-depth report of where we stand today on a large array of themes, topics, issues and evidences. I would recommend especially the key entry "Political Communication," written by one of founding fathers of the discipline: Jay G. Blumler. He gives a sharp account of what has been achieved in the field and of what is still relevant and valid (an "enduring foundational legacy"), from four perspectives: 1) effects, 2) systemic, 3) dynamic and 4) normative. He still considers usable theories and lines of research such as agenda setting, framing, priming, constructivism, selective exposure, mediatization, comparative media systems, commercialization of news, modern publicity process, personalization, journalism roles, crisis of public communication, and many others.

Blumler lists also the directions for future research: perceptions of opinion climates in the digital public sphere, extent of political knowledgeability via the internet, modes of political discourse, new forms of participation (online/ offline), hybridized political communication.

In a word, there is a rich landscape of research venues before us, and more are emerging.

New generations of citizens (and voters) are familiar with new technologies (online media, social media, high speed internet, interactivity of mediated communication). But what about the politicians? Are they as skillful as the voters? Do they know really how to use the technology for their own purposes?

Let's make one thing clear: not all leaders and politicians in the mass communication age excelled for particular communication capabilities. Some showed a distinct charisma, some others fared poorly. To give an example: John Kennedy was brilliant and effective, Richard Nixon the opposite. Yet, also in the old days, many of those who wanted to run for office relied on spin-doctors and media wizards. A loser like Nixon finally won a presidential bid thanks to the new public image rebuilt by shrewd political marketing shamans, as narrated in the book The Selling of the President (J. McGinniss, 1968). This to say that current politicians also discriminate between those who do have natural skills and those 
who don't. Politicians like Donald Trump and Matteo Salvini show to possess communication clout that the other political leaders lack. They are capable to "speak to the guts", that is to strike the sensitive emotional chords of their audiences. That said, from a general observation of non-celebrity politicians in democratic countries, there is good evidence that most of them nowadays are fully aware that they should master digital media to be successful in their communicative engagements. It is also a feature of our times, the emergence of an entrepreneurial expertise in digital technologies readily available to, and increasingly employed, by politicians to mobilize consent. Voters - especially the younger generations - undoubtedly have achieved high levels of digital competence, forcing politicians to cater effectively to their demands and needs.

What are the main challenges that scholars face while they are studying changes in political communication these days?

Being myself part of a generation of scholars that for decades held mass communication as a pretty stable ecosystem, easy to dissect and analyze, I see the major challenges for the new generations of researchers in the breathless development of communication technology - that forces hasty shifts of interest from one new medium to the next, before we have grasped it sufficiently, and in the "liquid" nature of socio/political change that marks the present time. Moreover, the temptation for scholars to take the shortcuts of determinism (e.g. social media held as causes of the surge of populism), or of short sightedness (pursuing hyper-micro investigations and losing sight of the wider environment), is always a risk 'around the corner'. I still believe in strong theory, big research and a comparative approach.

Who is benefiting the most from the changes in the media technologies? Political actors? Citizens? Media?

When scholars speak of a "digital public sphere" they actually acknowledge the existence of a generalized achievement by the polity as a whole of a sufficient level of digitalization. It relates both to the media/communication competences and to the daily life administration of people. I have already mentioned how politicians are exploiting the affordances that digital media provide. Citizens have now gained access to communication channels that were inexistent in the previous age and that was a serious handicap in making their voice heard. Today, beside access they have reached an impressive level of empowerment that has allowed voters not only to voice their claims but also to affect politicians' communication strategies. We are witnessing a reverse of the "effects theory", where in the recent past we were studying what influence political communication of political actors exerted on the electorate, today we are investigating on how voters 
affect, for example by means of social media, candidates' campaign agendas. The populist leaders in Europe and elsewhere are in fact very responsive and adaptive to the moods and climates of opinion emerging from the cyber-sphere. The surge of "big data" research is closely related to the need to measure "what people say" on social media.

The traditional media are themselves promptly adjusting to the digital ecosystem. We see it every time we read the news online o watch a talk show on TV.

Is politics now all about a performance? What about the political agenda and ideology? Do they still matter?

I was and am still convinced that politics is fundamentally a power struggle lead by conflicting visions of the world. The definitions might change over time: socialism vs. liberalism, left vs. right, progressivism vs. conservatism, public vs. individual interest, sustainability vs. greed, and the like, but it is indistinctively a clash of ideologies. Communication and performance are at the service of those visions, making the difference in who is eventually the winner.

What are the main consequences of changes in the political communication for journalists?

Journalism, as we have known it, is facing a mighty challenge to its role in modern society and even to its very survival since the diffusion of social networks. The romantic 'citizen/participatory journalism' depicted enthusiastically by some digital optimists, with the spread of smartphones has turned into a 'nightmare journalism'. People produce, edit, diffuse and share all sorts of contents, photos, videos, comments on all sorts of events, driving corporate news media into a corner, definitely overriding their traditional role of gatekeepers and fact-checkers. The red-alert today for democracies (that are ideally rooted in informed citizenship) is on disinformation, that in a digital world is technically - and politically - impossible to obstruct. Journalists have to recast their 'mission' and build a new identity, that can recapture public trust, by focusing on severe selection of which events are of public interest, by redefining the criteria of newsworthiness, by specializing in exposing and debunking fake news. I like to imagine future journalism as a rescue boat rather than a warship, a safe space where citizens in bewilderment at the overflow of the dubious can find credible information!

Professor Gianpietro Mazzoleni was interviewed by Agnieszka Stępinska in February 2020. 
Gianpietro Mazzoleni served as Professor of Sociology of Communication and of Political Communication from 2002 to 2016 at the University of Milan (Italy). $\mathrm{He}$ is a member of the editorial boards of the European Journal of Communication, Journal of Political Marketing, Central European Journal of Communication, Problemi dell'Informazione (Il Mulino), and Sociologia della Comunicazione (Franco Angeli). He was also a member of editorial boards of Political Communication (1998-2015), International Journal of Press/Politics (2010-2015). In 2011-2015 he was an Editor-in-Chief of The International Encyclopedia of Political Communication, sponsored by the International Communication Association (ICA) and published by Wiley (2016). He served as a chair of Swanson Award Committee of the International Communication Association and of the American Political Science Association (2014-2016), as a President of the Associazione Italiana di Comunicazione Politica (2014-2019), and a chair of the Political Communication Division, International Communication Association (2005-2006). $\mathrm{He}$ is also a founder and head of the seven editions of the Milan International Summer School in Political Communication and Electoral Behavior (2007-2020). Currently (2019-2021) he is a member of the Fellows Book Award Committee of the International Communication Association (ICA)

\section{RECENT PUBLICATIONS}

Mazzoleni, G. \& Bracciale, R. (2019). La politica pop online. I meme e le sfide della comunicazione politica. Bologna: Il Mulino.

Mazzoleni, G. (Ed.). (2016). The International Encyclopedia of Political Communication, 3 volls., Wiley.

Fengler, S., Mazzoleni, G., Eberwein, T., Russ-Mohl, S., \& Porlezza, C. (Eds.). (2014). Journalists and media accountability. An international study of news people in the digital age. New York: Peter Lang. 